\title{
Study of household accident prone areas in rural Saharanpur
}

\author{
Manjeeta. ${ }^{1}$, Vikramaditya B. ${ }^{2 *}$, Shankar Joshi H. ${ }^{3}$, Kumar Jha A. \\ DOI: https://doi.org/10.17511/ijphr.2019.i3.05
}

\footnotetext{
1 Manjeeta, Junior Resident, Department of Community Medicine, SMMH Government Medical College, Saharanpur, Uttar Pradesh, India.

2* Bibhava Vikramaditya, Assistant Professor, Department of Community Medicine, SMMH Government Medical College, Saharanpur, Uttar Pradesh, India.

3 Hari Shankar Joshi, Professor and Head, Department of Community Medicine, SMMH Government Medical College, Saharanpur, Uttar Pradesh, India.
}

${ }^{4}$ Amit Kumar Jha, Professor, Department of Community Medicine, SMMH Government Medical College, Saharanpur, Uttar Pradesh, India.

Introduction: Household accidents cause injury to the affected individual along with stress and economic strain to the family. Studies on household accident prone areas in rural area of India are rare. Objective: The present study was conducted to assess the prevalence of domestic accidents and rural household accident prone areas. Methods: The study was done in the village Pilkhani, Saharanpur, Uttar Pradesh from October to December 2018. Sixty houses were randomly selected in the village. Information regarding household accident prone areas was gathered by interviewing the head of the family or the adult informant and accident prone areas were observed in the household. The analysis was done using MS Excel software. Results: Prevalence of domestic accidents was $8.25 \%$ with falls being the most common. Uneven brick/kacha floor, floor at different levels, improper electric fittings, fodder cutting machine and low clothes line were frequently found accident prone areas identified in the households. Conclusion: In order to prevent and control the domestic accidents, creation of awareness among the community and inculcation of household safety measures using Information Education and Communication interventions have to be strived for along with structural modification of accident prone areas in the household.

Keywords: Household, Accident prone areas, Rural, Saharanpur

Corresponding Author

Bibhava Vikramaditya, Assistant Professor, Department of Community Medicine, SMMH Government Medical College, Saharanpur, Uttar Pradesh, India.

Email: vikramadityabibhav@gmail.com

\section{How to Cite this Article}

Manjeeta, Vikramaditya B, Joshi HS, Jha AK. Study of household accident prone areas in rural Saharanpur. Public Health Rev Int J Public Health Res. 2019;6(3):126-131.

Available From

https://publichealth.medresearch.in/index.php/ijphr/ article/view/110
To Browse

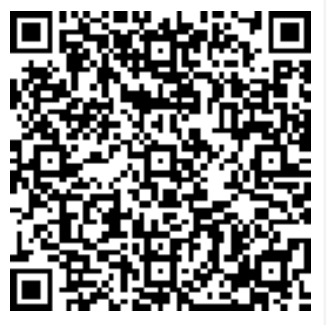

Manuscript Received 2019-06-08

Conflict of Interest No

Review Round 1
2019-06-18
Funding
Nil
(c) 2019 by Manjeeta , Bibhava Vikramaditya, Hari Shankar Joshi, Amit Kumar Jha and Published by Siddharth Health Research
and Social Welfare Society. This is an Open Access article licensed under a Creative Commons Attribution 4.0 International License https://creativecommons.org/licenses/by/4.0/ unported [CC BY 4.0]. 


\section{Introduction}

Accident can be defined as an unpremeditated event resulting in recognizable damage [1]. Increased incidence of accidents has resulted from a variety of contributing factors like population explosion causing overcrowding, increased mechanization of homes, industry and agriculture, neglecting safety measures for economic profits and lack of preventive education [2]. Presently accidents represent a major epidemic of non-communicable disease.

Domestic accident is an accident which takes place in the home or its immediate surroundings, and, more generally all accident not connected with traffic, vehicles or sport [3]. The problem of household accidents is greater in the developing countries, particularly in the rural areas [4]. Low socio-economy rural people living in unsafe overcrowded houses with risky practices are at higher risk of household accidents.

Household accidents can cause injury and morbidity to the affected individual along with mental stress and economic strain to the family members. Household accidents have their own natural history and follow the same epidemiological pattern as any other disease- the agent, host and environment interacting together to produce injury or damage [5].

There have been studies on burden, prevalence, type of domestic accidents and levels of awareness on its prevention but analysis of household accident prone areas has not been adequately undertaken in the rural area of India. In this background, the present study was conducted to assess the household accident prone areas in a rural community of Saharanpur and the information obtained may give an insight into the planners about the magnitude of the problem and the need for appropriate preventive measures.

\section{Aim \& Objectives}

Aim: To identify and assess the rural household accident prone areas.

\section{Objectives}

01. To find the prevalence of domestic accidents in rural area.

02. To identify the household accident prone areas in rural community.
03. To assess the prevalence of the identified rural household accident prone areas.

\section{Material and Methods}

Study setting: The study was carried out in the village Pilkhani Block Rampur Maniharan, District Saharanpur, Uttar Pradesh. The village is located in the field practice area of Department of Community Medicine, SMMH Government Medical College, Saharanpur.

Study period: The study was conducted from October to December 2018 (three months).

Study design: The present study was a descriptive cross sectional community-based study.

Sampling method: One villages were randomly chosen among all villages in ruralfield practice area. A total of sixty houses were randomly selected in the village. Interviews were conducted by house to house visits.

Ethical consideration and permission: Informed written consent was taken from interviewed adult family member after explaining to them the purpose of the study. If they refused to participate in the study or the house was locked the next randomly selected house number was substituted in its place.

The study was duly approved by the Institutional Ethics Committee of SMMH Government Medical College, Saharanpur.

\section{Exclusion criteria}

Inclusion criteria: Randomly selected houses of the village Pilkhani willing to participate in the study.

01. Refusal to participate.

02. Locked house.

Procedure of data collection: House visit was made and information regarding household accident prone areas was collected by interviewing the head of the family or the responsible adult family member present at home. Information about occurrence and type of domestic accidents among the family members in the past one year from the date of survey was obtained.

The accident prone areas were observed in the household and recorded. The details regarding the household structure and surrounding environment were recorded on the proforma. After the end of the interview suitable household accident prevention measures were explained to the family. 
Development of proforma: The proforma was developed in which household features were classified as safe and unsafe according to set criteria devised in accordance with guidelines of The Royal Society for the Prevention of Accidents [6].

The proforma was modified according to rural Indian scenario according to suggestions of senior faculty members of Department of Community Medicine, SMMH Government Medical College, Saharanpur. A pilot study was done on 30 houses in another village. Household accident prone areas observed in the pilot study which were not a part of the proforma were added to the proforma.

Statistical methods and analysis: The data obtained was tabulated and analyzed by using descriptive statistics, viz. Percentages with help of MS Excel software.

\section{Results}

Table-1: Type of domestic accidents among the study subjects $(n=17)$

\begin{tabular}{|l|l|}
\hline \multicolumn{1}{|c|}{ Type of domestic accident } & \multicolumn{1}{c|}{ Frequency (\%) } \\
\hline Falls and slips & $6(35.2)$ \\
\hline Burns & $1(05.9)$ \\
\hline Electrical shocks & $2(11.8)$ \\
\hline Injuries / Cuts by sharp instrument & $5(29.4)$ \\
\hline Drowning & $0(0.0)$ \\
\hline Accidental Poisoning & $2(11.8)$ \\
\hline Bites by insect or animal & $1(05.9)$ \\
\hline All domestic accidents & $17(100)$ \\
\hline
\end{tabular}

A total of 60 households were included in the study. There were total 206 individual members in the families. Altogether 17 household accidents occurred in the previous year. So, prevalence of domestic accidents was $8.25 \%$. (Table 1 ). Among the household accident falls comprised one third of the total accidents, followed by injuries and cuts by sharp instrument. There were two cases each of electrical shocks and accidental poisoning and one case each of burns and animal bite. There was no case of drowning. The household features observed were classified as safe and unsafe according to the proforma. (Table 2)

Table-2: Prevalence of Household accident prone areas $(n=60)$

\begin{tabular}{|l|l|l|}
\hline \multirow{2}{*}{$\begin{array}{l}\text { Accident prone area (Frequently found } \\
\text { criteria) }\end{array}$} & \multicolumn{2}{|c|}{$\begin{array}{c}\text { No of houses } \\
\text { (Percentage-\%) }\end{array}$} \\
\cline { 2 - 3 } & Safe & Unsafe \\
\hline $\begin{array}{l}\text { Building (Safe-Pucca and well built, Unsafe - } \\
\text { kuccha) }\end{array}$ & $56(93.33)$ & $4(6.67)$ \\
\hline
\end{tabular}

\begin{tabular}{|l|l|l|}
\hline $\begin{array}{l}\text { Floor (Safe-Pucca and level, Unsafe-Kuccha, slippery } \\
\text { and uneven) }\end{array}$ & $31(51.67)$ & $29(48.33)$ \\
\hline $\begin{array}{l}\text { Kitchen (Safe-Separate, LPG cylinder safely used, } \\
\text { Electric appliance used safely, adequate ventilation, } \\
\text { Unsafe-Unsafe usage of LPG, kerosene oil, coal, wood } \\
\text { and others, floor level cooking) }\end{array}$ & $32(53.33)$ & $28(46.67)$ \\
\hline $\begin{array}{l}\text { Stairs/ Ladders (Safe-Well built staircase with } \\
\text { supporting side rails, Unsafe-Slippery steps, steep } \\
\text { gradient, portable ladder) }\end{array}$ & $39(65)$ & $21(35)$ \\
\hline $\begin{array}{l}\text { Roofs (Safe-Well built with parapets, Unsafe-No } \\
\text { parapets) }\end{array}$ & $35(58.33)$ & $25(41.67)$ \\
\hline $\begin{array}{l}\text { Electric Fittings/ Motors (Safe-No overload, properly } \\
\text { fitted plugs, Unsafe-Loose wires) }\end{array}$ & $44(73.33)$ & $16(26.67)$ \\
\hline $\begin{array}{l}\text { Illumination (Safe-Adequate, Unsafe-Inadequate) } \\
\text { place) }\end{array}$ & $40(66.67)$ & $20(33.33)$ \\
\hline $\begin{array}{l}\text { Machine (fodder cutting, tractor etc.) } \\
\text { children, medicines stored properly in cool and dry } \\
\text { like kerosene etc.) }\end{array}$ & $36(60)$ & $24(40)$ \\
\hline Clothes Line (Unsafe-Low height) & $52(86.67)$ & $8(13.33)$ \\
\hline
\end{tabular}

The table highlights that majority of houses had safe building structure. Almost half of the homes had unsafe floor and kitchen.

One third of households had unsafe stairs and inadequate illumination. Quarter of houses had loose electrical wires. Unsafe storage of fodder cutting machine, roof with no parapets, low clothes line and hazardous substances which can cause fire was seen in about $40 \%$ of houses. Unsafe storage of poisons and drugs were in $13 \%$ of houses.

\section{Discussion}

The prevalence of domestic accidents was $8.25 \%$ in the present study. Study by Masthi et al. in rural areas of Bangalore, Karnataka, covering a population of 44,387 in the period from January to December, 2009 found prevalence of $9.6 \%$ in the rural community [7]. Study by Radhakrishnan et al. in rural community of Salem, Tamil Nadu from January to December, 2014 found the overall prevalence of domestic accident was $13 \%$ [8].

Another study by Sudhir et al. conducted in rural Mysore from January to December 2010 observed the prevalence of domestic accidents among the rural population was $9.4 \%$ [9]. Study by George et al. at rural Kerala from April to May, 2016 observed the overall prevalence of domestic accident was $10.5 \%$ [10]. 
Netra et al. in a study in urban Davangere, Karnataka from September to November, 2016 found the overall prevalence of domestic accident was $5.2 \%$ [11].

However, cross sectional study conducted from September to December 2005 by Bhanderi et al. in a semi-urban community found incidence of domestic accidents was found to be $1.7 \%$ [12]. This difference in the prevalence may be because the study was done in semi urban area and over a decade ago and duration of study was 6 months; whereas, the present study was done in rural area and for a period of one year.

The present study revealed that falls and slips were most common domestic accidents followed by injuries and cuts by sharp instrument. Study by George et al. reported falls were the most common domestic accident (33.5\%) followed by burns/scalds (20.4\%) and injury by sharp instruments (18.8\%) [10]. Study by Masthi et al., Radhakrishnan et al., Sudhir et al., Netra et al. and Bhanderi et al also observed that falls were the most commonly reported domestic accident [7-9, 11-12].

However, in the studies conducted by Avsarogullari et al. in Turkey, Marsh et al. in Pakistan and Neghab et al. in Shiraz, Islamic Republic of Iran burns were the most common domestic accidents [13-15]. This variation may be owing to difference in socio cultural practices and level of awareness.

The present study revealed that half of the homes had unsafe floor and kitchen. Study by George et al. concluded that proper designing of house and surroundings is important [10]. Study by Radhakrishnan et al. and Sudhir et al. observed courtyard and kitchen to be common place for domestic accidents [8, 9].

Study by Shawon et al. carried out in a rural community in Bangladesh in March 2011, also observed courtyard and kitchen were the common places for domestic accidents [16]. In the present study, the one third of households had unsafe stairs and inadequate illumination.

Study by Netra et al. concluded that there is a need for adequate lighting during evening hours as well as proper designing of house to make it elderly and children friendly [11]. Bhanderi et al. also concluded that proper designing of house and adequate illumination may help in reducing occurrence of domestic accidents [12].
In the present study, quarter of houses had loose electrical wires and unsafe storage of poisons and drugs were in $13 \%$ of houses. Cross sectional study by Sirohi et al. in urban areas of Indore, Madhya Pradesh from October 2013 to January 2014 also found majority of respondents were unaware about proper storage of medicines and electricity safety measures [17].

\section{Limitations}

As the present study design is cross-sectional and information was collected from only one adult informant in each house there may have been recall bias. Further the study was undertaken with a small sample in rural area of Saharanpur and may not be representative of entire population.

\section{Conclusion}

The cause of household accident depends upon the inappropriate housing conditions and the indoor and outdoor surrounding environment. Several studies have shown falls to be commonest type of domestic accident [7-12]. The prevention of household falls can be effectively done by removing the variations in floor level, avoiding wet slippery surface and correcting uneven floor. Installation of stair hand rails, parapets, fences are safety measures to be taken in majority of houses. Frequent use of portable ladder as seen in many of the houses must be avoided as they can lead to fall from height.

Illumination should be improved in working area and overcrowding must be avoided. People should be made aware of hazards of floor level cooking. Loose and naked wire electrical fittings should be corrected with plugs. Improving the play space for children should be done. Parents need to maintain supervision on young children and should store poisons, pesticides and drugs safely in locked high cupboards away from children's reach.

Empty pesticide containers should not be used for storing food or water. Fodder cutting machine commonly seen in rural houses must be kept and operated safely. Fuels like kerosene need to be stored safely. During the present study appropriate household safety measures were advised by the investigator after the interview and were appreciated by the household members.

Recommendations: Simple structural modification can be done in existing houses to correct the accident prone areas. 
Health education of rural people is an important tool to create awareness, motivation and inculcation of household safety measures for prevention of household accident.

\section{What the study adds to the existing knowledge}

The study adds to our understanding about the household accident prone areas. The study would be a guide for further community-based research with large sample involving almost all age groups in various part of country.

\section{Authors Contribution}

Manjeeta worked in data collection and data tabulation.

Bibhava Vikramaditya was principal investigator and wrote the manuscript.

Hari Shankar Joshi guided in editing manuscript for corrections and proforma development and review.

Dr. Amit Kumar Jha guided in finalization of manuscript and proforma development and review.

\section{Acknowledgements}

Authors are thankful to PHC, Pilkhani for their support

\section{Reference}

01. WHO. Techn. Rep. 1957; Ser No-118.

[Crossref]

02. Sunder Lal, Adarsh, Pankaj. Epidemiology of Non-Communicable Diseases and Related National Health Programmes, In-8 Text book of Community Medicine. 4th ed, CBS Publications; New Delhi. 2014.

[Crossref]

03. Govt of India. Swasth Hind. 1979;25(12)329.

[Crossref]

04. Galal S. Working with families to reduce the risk of home accidents in children. East Meditr HIth

J. $1999 ; 5(3) 572-582$.

[Crossref]

05. Park K. Epidemiology of Chronic Non-Communicable Diseases and Conditions, In- Park's Text Book of Preventive and Social Medicine. 25th ed, Bhanot Publications; Jabalpur. 2019. [Crossref]
06. The Royal Society for the Prevention of Accidents. Preventing Accidents in the Home. 2019 [updated 2019 Mar 25; cited 2019 Jun 10].

Available from: [Article] [Crossref]

07. Ramesh Masthi NR, Kishore SG, Gangaboriah. Prevalence of Domestic Accidents in the Rural Field Practice Area of a Medical College in Bangalore, Karnataka. Indian J Public Health. 2012;56(3)235-237. doi: 10.4103/0019-557X.104262 [Crossref]

08. Radhakrishnan S, Nayeem A. Prevalence and factors influencing domestic accidents in a rural area in Salem district. Int J Med Sci Public Health. 2016;5(8)1688-1692.

doi: $10.5455 /$ ijmsph.2016.09122015287 [Crossref]

09. Sudhir, Krishna D, Channabasappa AN, Dhar M. Prevalence of domestic accidents in rural Indiaa cross-sectional study. Sch J App Med Sci. 2014;2(2B)657-659.

[Crossref]

10. George S, Paul N, Francis PT, Leelamoni K. Prevalence of domestic accidents in a rural area of Kerala- a cross sectional study. Int J Community Med Public Health. 2017;4(4)949953.

doi: $\quad 10.18203 / 2394-6040 . i j c m p h 20170949$ [Crossref]

11. Netra G, Nawaz AS, Kumar A, Kusum M, Rao BAV. A cross-sectional study on domestic accidents in the urban field practice area of a private medical college, Davangere, Karnataka. Int J Community Med Public Health. 2017;4(9)3354-3359.

doi: $\quad 10.18203 / 2394-6040 . i j c m p h 20173844$ [Crossref]

12. Bhanderi DJ, Choudhary S. A study of occurrence of domestic accidents in semi-urban community. Indian J Community Med. $2008 ; 33(2) 104-106$.

doi: $10.4103 / 0970-0218.40878$ [Crossref]

13. Avsarogullari L, Sozuer E, Ikizceli I, Kekec Z, Yurumez Y, Ozkan S. Adult burn injuries in an Emergency Department in Central Anatolia, Turkey- a 5-year analysis. Burns. 2003; 29(6)571-577.

doi: [Article] [Crossref] 
14. Marsh D, Sheikh A, Khalil A, Kamil S, Jaffer-uzZaman, Qureshi I, et al. Epidemiology of adults hospitalized with burns in Karachi, Pakistan. Burns. $1996 ; 22(3) 225-229$.

doi:10.1016/0305-4179(95)00114-X [Crossref]

15. Neghab M, Fard RA, Habibi M, Choobineh A. Home accidents in rural and urban areas of Shiraz, 2000-2002. East Mediterr Health J. $2006 ; 12(6) 824-833$.

[Crossref]
16. Shawon SR, Hossain FB, Rahman M, Ima SZ. Domestic accidents in a rural community of Bangladesh- a cross-sectional study on their incidence and characteristics. Develop Countr Stud. 2012;2(7)14-19.

[Crossref]

17. Sirohi S, Pandey D, Dixit S, Jain C, Deshmankar $B$, Raja RS. Domestic accidents- an emerging threat to community. Int J Med Sci Public Health. 2015;4(9)1202-1205.

doi: $10.5455 /$ ijmsph.2015.14012015237 [Crossref] 